\title{
Al-Quran Learning Through Information Processing Model Ala Joyce and Weil MTs Works in The Village Lara Mulya Baebunta District District North Luwu
}

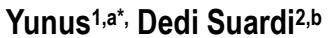 \\ ${ }^{1}$ Faculty of Engineering STMIK Eresha Pamulang \\ ${ }^{2}$ Karya Mulia village MTs Teachers Lara \\ nurhang542@gmail.com \\ ${ }^{*}$ Corresponding Author
}

How to Cite : Yunus, Y., Suardi, D. (2019). Al-Quran Learning Through Information Processing Model Ala Joyce and Weil MTs Works in The Village Lara Mulya Baebunta District District North Luwu. International Journal for Educational and Vocational Studies, 1 (2), 104-108.

\section{ARTICLE HISTORY}

Received:3 April 2019

Revised: 20 May2019

Accepted: 29 May 2019

\section{KEYWORDS}

Learning the Quran,

Ala Joyce,

Weil Information Processing Model

\begin{abstract}
The study is executed with Actions Observational method braze (PTK). This research is executed at MTs Mulya's Opus with the subject of research student brazes VII by a total of 22 students, 1 teacher and Headmaster. Acquired Data source of that student covers, formative student essay in work problem that is given at the early cycle. Observation sheet result to measure the result step-up studies student with implemented a model of Information proceedings. Observation result and field note that gets bearing with student activity's learning on al Qur 'an happens. Observational result and the analysis concludes that deep upgrade in observational learning.1). Proceedingses implement models models suit to arouse student information point and student studying with information yen proceedings concept has a mission to help the student to concentrate at one particular domain the which they can gain control. Observation/control, helping student develops conceptual grasp about a particular domain. 2). Learned yielding step-up student of each cycle, the which is on essays average value interest quiz 69 on 1. cycle is average value of 68.4 and on cycle IV. average value is 76.77 .3 . Interference in implementation is as follows: 1 ) student were given by the task extant a portion out of focus little deep and serious solve that task, 2) reducings the late understating of material already being taught by the teacher were the caused by reducing it concentrate while word teacher.
\end{abstract}

This is an open access article under the CC-BY-SA license.

\section{INTRODUCTION}

Education as a human resource development efforts is a solution to the acquisition of knowledge to be able to take advantage of technological advances in facilitating the activities of life. This was disclosed by Sutaryat Trisnamansyah said "education is closely related to human capital potential in increasing the income a person's work" (Sutaryat Trisnamansyah, 1979). Innovation education and learning is the right step in addressing the problems in the education process in general and in particular the learning process. Thus, learning innovations can be implemented educators to improve weaknesses in the learning process, so as to achieve maximum results.

Educators need to understand the dynamics of change and develop creativity educator capacity to absorb, adapt, produce or refusing renewal itself (Cece Wijaya. 1992). Thus, the learning model is an effort to align the development of science and technology into the learning pr- ocess and at the same time to solve various problems in the learning process, as said Nurul Zuriah and Day Sunaryo "model in the field of education and learning is an attempt to solve the problems in education and learning "(Nurul Sunaryo Zuriah \& Day, 2009).

Quality learning process refers to Law No. 20 of 2003 on national standards for Chapter IX of article 35, paragraph 1 "national standard of education that is the standard content, process, competence of graduates, staff, facilities and infrastructure, management, financing, and assessment of education must be improved in a planned and periodic (Education. 2003).

The learning process of this kind can only be implemented through learning that designing effective learning to consider and use a variety of things optimally, such as choosing teaching methods appropriate to the characteristics of the subject matter, create media that attract and harness the potential of learners so that they 
can be involved in the learning process. In addition to that the quality of learning process should also pay attention to the condition of the individual learner as a unique individual, and uniqueness that should receive attention in the learning process.

Learners become one determinant in considering and implementing instructional methods and media appropriate to the characteristics of learners. Thus these components is well aligned to realize the quality of learning.Reform of learning are being developed in Indonesia, teachers or prospective teachers currently offered with a selection of many learning models, which sometimes for the sake of empirically (academic research and action research) is very difficult menermukan literarturnya sources. However, if the teachers (teacher candidates) have been able to understand the concept or the basic theory of learning which refers to the process (along with concepts and theories) learning as described above, then basically the teachers were able to creatively try out and develop a learning model a distinctive, in accordance with the real conditions in the workplace each, so that in turn will show models of learning the teacher version, which of course further enrich the learning model that already exists.

MTs Karya Mulya village Baebunta Lara District of Luwu Utara is schools with learners with karakeristik and backgrounds are very diverse. Learners can run the routine religious smoothly without any interruption so that religious activity learners are very strong in their daily life, for example when a midday arrived, the students immediately stop their activities and straight to the mosque, adhan, giving Kultum, and become a priest prayer, the entire series the worship carried out by learners themselves even in shopping for food and beverages in the school cafeteria, the students themselves were counting the number of bills of food and beverages consumed, so that personal reflected honest in self-learners. Learning the Koran currently less showed satisfactory results. Because there are still many problems that lead students to be less enthusiastic about such subjects, among others: 1) Facilities and infrastructure are inadequate (lack of textbooks for learners). 2) Learning to do less to attract learners so that learners are easily bored and less active learners. 3) The achievement of learners is low.

A teacher is able to instil the concept of material well and create a classroom atmosphere conducive to the classroom atmosphere inspires the spirit learners to follow the course of the Koran and Hadith were able to improve the performance of learners using appropriate learning models at the time learners getting fed while following the course of the lesson. The learning model is a plan or pattern that can be used to shape the curriculum, designing learning materials, and guiding learning in the classroom or the other. Clumps learning model consists of four models of learning, ie learning models of information processing in the style of Joyce and Weil, learning models of social interaction, personal learning model and learning model behavior. Clumps learning model is based on the information that is where the cognitive learning theory oriented to the ability of learners process information. Information processing model of learning style of Joyce and Weil also has a learning model grove again, namely inductive thinking models, models of practice inquiry, scientific inquiry, discovery concept, cognitive growth, advanced styling and memory models.

For students of MTs Karya Mulya application processing model is very important, because it can improve the quality of learners' intellectual good of cognitive aspects ,. In addition the use of processing model is expected to provide a positive influence for students and improve student learning outcomes. Based on the experience that researchers face in the process of learning the Koran that are inactive, the researchers tried to find another teaching model, so that the learning more meaningful and better quality.

The application of information processing model in the style of Joyce and Weil is one of the efforts made by educators in improving student learning outcomes in learning the Koran in class VII application of information processing model ala ala Joyce and Joyce \& Weil Weil with the aim to improve learning outcomes in students of class VII MTs. Mulya works on learning the Koran is expected to motivate students to be more active in the learning process. To achieve the expected value corresponding 70 minimum completeness criteria (KKM) were determined.

\section{Model Ala Information Processing Joyce and Weil}

Joyce and Weil defines learning model as a "conceptual framework used as a guide in learning" (Joyce, B., \& Weil, 1980). Thus, the learning model is a conceptual framework that describes a systematic procedure in organizing learning experiences to achieve the learning objectives. So learning models tend to be prescriptive (in reaching objectives), which is relatively difficult to distinguish from learning strategies. And strategies for learning is an instructional strategy is a method for delivering instruction that is intended to help students Achieve a learning objectiv e (Burden, PR, \& Byrd, DM 1996).

Understanding some of the statements above how necessary and important learning model presented in the learning process so that the circumstances pemebelajaran be good and purposeful. Bruce Joyce and Marsha Weil categorization learning model as follows: (Bruce Joyce Marsha Weil, Models Of Teaching, 2003).

Teaching model for developing creative domains (cognitive). Including information processing model is a model of increasing the capacity of thinking inspired by Jean Piaget. Application of this model is directed at the following developments:

a. Resourceful student creativity

b. Students' critical thinking

c. Independent assessment of students

After the teacher to prepare everything that supports the presentation, such as props, book resources, he must be 
prepared to carry out three kinds of syntax models. These measures are usually taken using discussion and tasks briefly be described as follows:

a) Step confrontation, the teacher confronts or exposes students to the problems of opposing, full of question marks, and sometimes absurd. The trick is to menajukan thorny question but still equivalent to the cognitive development of students.

b) Step inquiry, is the process of students' use of intellect in acquiring knowledge by finding and organizing the concepts into an order that the students feel are important. During the inquiry process teachers need to provide opportunities for students to more develop their own creativity in solving problems.

Transfer step, at this late stage is expected capabilities realm of copyright and taste already possessed by students to facilitate the completion of next-learning tasks completion. In addition, the students' cognitive issue in solving the problem is expected to have a positive effect or can be used again to solve new problems.

\section{METHODS}

This type of research is action research, this study used a model of action research and Taggart Kemmis book Asrori Muhammad, the spiral-shaped and one cycle to the next cycle. Each cycle includes planning (plan), action (action), observation (observation) and reflection (reflection). (Muhammad Asrori, 2008). The next step in the cycle is a revised planning, action, observation and reflection.

In the implementation of the Action Research (PTK) there are two types of data that can be collected by researchers: 1) Qualitative data is data in the form of information to form a sentence that gives an overview of the expression of the students about the understanding of a subject (cognitive), views or attitudes of participants learners to a new learning medium (affective), the activity of learners to learn, attention, self-confidence, motivation to learn and interests and the like can be analyzed qualitatively. (Sugioyono. 2012).

Researchers using qualitative analysis techniques to analyze data on the observation and documentation. 2) The quantitative data (value learning outcomes of students), students learn the test results were analyzed quantitatively. To locate the average value of the study of students and the percentage increase in the study of students follow the applicable criteria as defined by Anas Sudijono as follows: (Anas Sudijono, 2006).

$\begin{array}{llcc}\text { No. } & \text { Number } & \text { Alphabet } & \text { Category } \\ \text { 1. } & 80-100 & \text { A } & \text { Very well } \\ \text { 2. } & 66-79 & \text { B } & \text { Well } \\ 3 . & 56-65 & \text { C } & \text { Enough } \\ 4 & 46-55 & \text { D } & \text { Less } \\ 5 & 0-45 & \text { E } & \text { Failed }\end{array}$

Besides, Hendri Yanto in thesis writing down the formula to determine the learning outcome of each cycle used quantitative analysis as follows:

$\mathrm{P}=\frac{\text { post Rate-Base Rate }}{\text { Base Rate }} \times 100 \%$

Information:

$\mathrm{P} \quad=$ percentage increase

Post Rate $=$ Average after action

base Rate $=$ Average before action.

(Ngalim Purwanto, 2008)

In this study, this study used qualitative data analysis flow models of Milles and Huberman in Eko Yuli Tatag Siswonwo, which includes three things:

1) Reduction of data (data reduction)

2) Presentation of data (Data display)

Drawing conclusions (Conclucion drawing) (Eko Yuli Tatag Siswono, 2008).

\section{RESULTS AND DISCUSSION}

\section{Results}

Basically processing model can help learners gather information and test it thoroughly, process the information into concepts and learn to manipulate these concepts. Used gradually, this strategy can also improve the ability of learners to create concepts efficiently and increase the range perceptive of which side they look at the information. Prior to the study by applying the model of the first information processing researchers took a competency test to learn the test results of students in the subject teachers as a comparison result of learning pre-cycle, the first cycle and the second cycle, the third cycle, the cycle IV.

Information processing theory stems from the assumption that learning is a very important factor in the development. The development of a cumulative result of learning. According to this theory, learning is a process of managing information, but this theory assumes sisitem processed information which will be studied learners are more important. Because the information is what will determine the process and how the learning process would take place would be by the information system are studied.

The phases that are external events that can be structured by students or teachers. Each phase is paired with a process that occurs in the mind of the learner. The events of that study will be described below, namely:

a. Phase motivations: learners that learning should be motivated to call the previously learned information. 
b. Phase introduction: students should pay attention to the essential parts of an instructional events, if learning will occur.

c. Acquisition phase: if the students pay attention to relevant information, then he was ready to receive lessons.

d. Retention phase: the newly acquired information to be transferred from short-term memory into long-term memory. This can happen through penggulangan back

e. Phase dialing: dialing can be helped by taking into account the linkages between the concept, especially among the new knowledge to prior knowledge.

f. Phase generalization: that information is usually less than its value, if it can not be applied outside the context in which the information was learned.

g. Phase appearance: behavior can be observed. Learning occurs when the stimulus affect the individual such that its performance is unchanged from the situation before the situation after learning to learn.

h. Phase feedback: the learners have to obtain feedback on their performance that indicates whether they have or have not understood what I was taught.

The application of the theory is wrong in learning situations result in a learning process that is very unpleasant for students that teachers as central as authoritarian, communication takes place in one direction, teacher training and determine what should be learned disciples. The use of penalties is avoided behavioristik leaders considered the most effective method to curb learners.

The assumption underlying theories describes information processing (1) the nature of human memory system, and (2) how knowledge is described and stored in memory. The old conception of the human memory is that memory was solely a storage area to store information for a long time, so the memory is defined as a collection of small pieces of information that escapes-off or no relation to each other. However, in 1960 the human memory began to be seen as a complicated structure to manage and organize all human knowledge.

This method is particularly suited to the acquisition of skills requires practice and habituation which contains elements of flexibility spontaneity speed endurance. This theory is also appropriate to train children who still need the role of parents. Disadvantages of this method is the education of students who are mechanistic teacher-centered and results-oriented only. Pupils deemed passive, students just listen, memorize the explanation of teachers so teachers as central and authoritarian.

Process information in memory starting from the process of encoding information (encoding), followed by information storage (stroge) and end with a revealing back informas-information that has been stored in the memory (retrieval). Learning theory describing the information processing action learning is an internal process that includes several stages.
Encodingis the process of entering information into memory. The nervous system uses an internal code that represents the external stimulus. In this way the representation of the object / external events are coded into internal information and ready to be stored.

Strogeis the information taken from short-term memory and then forwarded to be processed and incorporated into long-term memory. But not all of the information from short-term memory can be saved. Is key to long-term memory storage is sufficient motivation to encourage their repeated practice things from short-term memory.

Retrievalis the end result of the process of memory. Referring to the use of the information stored. In order to be retrieved, stored information is not only available but also can be obtained because although theoretically stored information available but it is not always easy to use and place. There are several steps that must be done in a learning model of cognitive growth, namely:

\section{Stage orientation}

At this stage the condition of teachers of students in a position to do the learning. Orientation phase is done by, first, an explanation goals to be achieved both objectives related to the mastery of the subject matter that must be achieved, as well as objectives relating to learning or thinking skills that must be possessed of learners. Secondly, the explanation process of learning to be done learners, which is an explanation of what to do learners in every stage of the process of learning.

\section{Phase tracking}

Phase tracking is exploratory phase to understand the basis of the experience and ability of learners in accordance with the theme or issue to be discussed. Through this phase teachers develop a dialogue and questions and answers to demystify the experience of what has been owned learners that are deemed relevant to the theme that will be studied.

\section{Phase confrontation}

Confrontation stage is the stage presentation of the problem to be solved in accordance with the level of ability and experience of the learners. To stimulate an increase in the ability of learners at this stage the teacher can give the issues a dilemma that requires an answer or a way out. At this stage the teacher should be able to develop a dialogue so that students really understand the problem to be solved.

\section{Phase inquiry}

At this stage the students learn to think real. Through inkuri stage, learners are invited to solve the problems faced. At this stage the teacher should give space and opportunity to develop ideas in a problem-solving efforts. Through a variety of techniques to ask the teacher to be able to cultivate the courage learners so that they can explain, reveal the fact in accordance with their experience, provide a convincing argument, developed the idea and so forth. 


\section{Phase accommodation}

Stage property is the stage of formation of new knowledge through a process of inference. At this stage, the students are required to be able to find the key words appropriate to the topic or theme of learning. At this stage through dialogue, the teacher guides so that learners can infer what they find and they understand about the topic in question.

5. Phase transfer

Transfer stage is the stage presentation of new issues commensurate with the issues presented. Phase transfer is intended as a stage so that learners are able to transfer the ability to think every student to solve new problems. At this stage the teacher can give assignments that match the topic of discussion.

In the classroom action research (PTK), by applying the information processing model in the style of Joyce and Weil on the subjects of the Koran is done in four cycles. The learning model is a model of information processing that provides an opportunity for teachers to express their own opinion. Based on the results showed an increase in the Qur'an learning outcomes of students of class VII M.Ts. Mulya work. Once applied models of information processing in the style of Joyce and Weil and KKM with the letter al-Luqman material obtained values averaged 76.77 .

As for the particulars of the learning outcomes of students score during the study of phase IV competency test until the cycle is as follows:

\begin{tabular}{lccc} 
Exam & Max & Min & Average \\
\hline Competention & 87 & 58 & $69 \%$ \\
I cycle 83 & & 35 & $68.4 \%$ \\
Cycle II 87 & & 59 & $70.6 \%$ \\
Cycle III 83 & 69 & $74.49 \%$ \\
Cycle IV 88 & & 70 & $76.7 \%$
\end{tabular}

Based on the table above shows an increase in the study of students of each cycle, ie the competency test test average value of 69 in the first cycle is an average value of $68.4 \%$ and in the fourth cycle of the average value is 76.77 .

In addition to an increase in the value of the study of students in the application of information processing model in the style of Joyce and Weil, there are changes in the activity of learners with the application of information processing in the style of Joyce and Weil. Although this model can improve the quality of learning and yet there are still many obstacles in the implementation of this model include:

\section{CONCLUSION}

Teachers who consider models of information processing in the style of Joyce and Weil as a strategy that could not be applied because it is not appropriate to the culture and the education system in Indonesia. Indeed, to change a habit is not easy work, especially the attitude of teachers who tend to be conventional, it is difficult to accept reforms.

\section{REFERENCES}

Anas Sudijono. (2006). Pengantar Evaluasi Pendidikan, Jakarta: Raja Grafindo Persada, 35.

Asrori, Muhammad. (2008). Penelitian Tindakan Kelas, Bandung: Wacana Prima, 54.

Joyce, B., \& Weil, M. (1980) Model of teaching, New Jersey: Prentice-Hall, Inc., 33.

Joyce, B., \& Weil, M., (2003) Models Of Teaching, (Prentice. HaII of India New Private Limited, 135.

P. R., Burden, \& Byrd, D. M. (1996). Method for effective teaching, second edition, Boston: Allyn and Bacon, 85.

Purwanto, Ngalim. (2008). Prinsip-prinsip dan Teknik Evaluasi Bandung: Rosdakarya, 103.

Sugioyono. (2012). Metode Penelitian Pendidikan, (Cet. XV; Bandung: Alfabeta, h. 17.

Sutaryat Trisnamansyah. (1979). Pengembangan Kualitas Sumber Daya Manusia, Jakarta: Aksara, 13.

Undang-undang SISDIKNAS (Sistem Pendidikan Nasional) (2003), Jakarta: Sinar Grafika, 18.

Wijaya, Cece, dkk. (1992). Upaya Pembaharuan dalam Pendidikan dan Pengajaran, Bandung: Remaja Rosdakarya, 4-5.

Yuli Eko Siswono, Tatag, (2008) Mengajar \& Meneliti, Surabaya: Unesa University Press, 29.

Zuriah, Nurul dan Hari Sunaryo. (2009). Inovasi Model Pembelajaran Berperspektif Gender, Teori dan Aplikasinya di Sekolah, Malang: UMM Press, 2. 